\title{
Protein requirements for catch-up growth
}

\author{
BY ALAN A. JACKSON \\ Department of Human Nutrition, University of Southampton, Bassett Crescent East, \\ Southampton SO9 $3 T U$
}

As has been noted by other speakers in this symposium, growth is frequently used as a non-specific term to include a constellation of changes associated with the elaboration of form and function. The changes in form are most readily identifiable as an increase in linear stature and mass, but also include more subtle variations in the composition of the body and changes in the relative size of the different organs and tissues. The development and refinement of function may be more difficult to quantify and is not as clearly characterized, although of no less importance. My comments will not include any considerations of function, other than in the most general sense. Later speakers will consider in detail the factors at the cellular and molecular level which might contribute to influence incremental height gain and the complexities of these interactions. It is not as yet clear how these influences are integrated in the whole animal.

\section{THE CONCEPT OF CATCH-UP GROWTH}

If the concept of catch-up growth is that of accelerated weight gain, then it is possible to define a spectrum of conditions for which the nutritional requirements must vary (Fig. 1). Growth is the normal state in childhood, and an abnormal slowing of the rate of growth will result in a progressive falling away from the normal growth channel. As growth is canalized a return to the original growth channel requires an acceleration in the rate of growth. By and large the tissue deposited during the process of acceleration will have a composition that is essentially similar to that deposited during normal growth. At the other extreme is the repletion of tissue in an individual, adult or child, who has experienced a period of active weight loss. The weight loss from different tissues is not balanced. There is relative preservation of visceral tissues at the expense of muscle and adipose tissue. Thus, the requirements for repletion of tissues is unbalanced in relation to the requirements for normal growth or maintenance. The greater the deficit or damage to be repaired, the more unbalanced is the tissue that needs to be regained. Therefore, one may conclude that if the losses are uneven between individuals, then the desirable gains need to be of variable composition. Hence, any assessment of requirements for catch-up growth needs a consideration of the composition of the tissue to be gained. My comments will focus on catch-up growth in humans as measured by a rate of increase in weight that is substantially greater than the normal rate of weight gain for chronological or developmental age. There are three models that have been usefully used to study the features of catch-up growth, preterm infants in whom the objective is to achieve rates of growth similar to that which obtains in utero; children during recovery from severe undernutrition: and in adults recovering from the stress of trauma, infection or surgical intervention. Although there are important differences between the different states, there are also areas of broad similarity. 


\section{Catch-up growth}

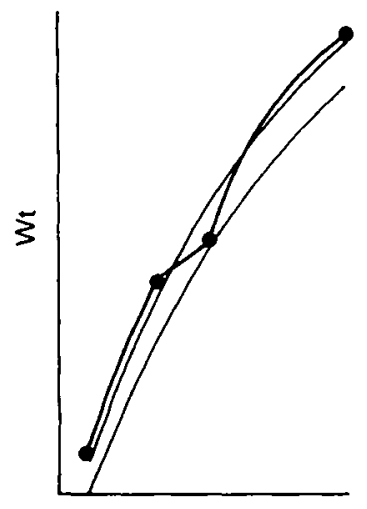

Balanced

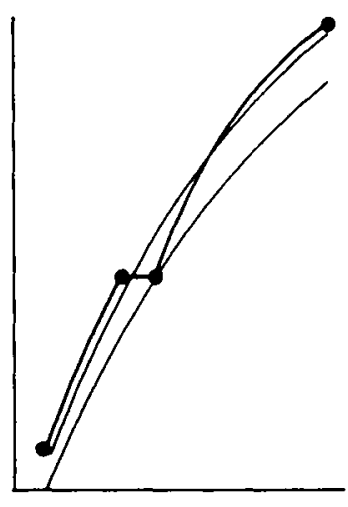

Time

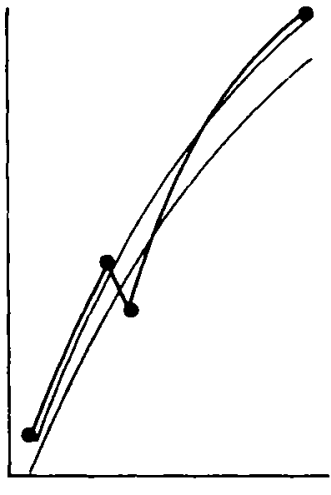

Unbalanced

Fig. 1. Growth and body composition are normally canalized. so that following a period during which growth has been delayed or weight has been lost. there is an acceleration in the rate of weight gain called catch-up growth. The nature of the tissue which should be deposited during catch-up growth is determined by the pattern of tissue lost. This pattern will be more unbalanced the greater the degree of weight loss.

\section{NUTRITIONAL DETERMINANT OF CATCH-UP GROWTH}

As growth represents an increment in the net energy content of the body. energy intake must exceed energy expenditure for tissue deposition to take place. Our interest is in the extent to which protein intake might modulate the extent and pattern of energy deposition during catch-up growth. Up to 1961 there was a general impression that the rate of weight gain should be determined by the dietary protein intake. However, based on a series of balance studies Waterlow (1961) noted: 'The rate of weight gain depends more closely on the intake of calories than of protein within the range studied (100 to 200 $\mathrm{kcal} / \mathrm{kg}$ per d, 2-7 g protein $/ \mathrm{kg}$ per d). For $150 \mathrm{kcal} / \mathrm{kg}$ per d a protein intake of $3-4 \mathrm{~g} / \mathrm{kg}$ per $d$ is adequate.' Later studies in which measurements where made of changes in weight and protein turnover during catch-up growth tended to reinforce this impression. The rate of weight gain was found to correlate with and respond to the intake of energy (Ashworth, 1979). There appeared to be little relationship between the rate of protein synthesis and the intake of protein, although protein turnover increased with an increase in energy intake (Golden et al. 1977).

The advantage in exploring the protein requirements for weight gain is that the weight can be measured with considerable reliability and reproducibility. However, the danger and disadvantage is that there is a tendency to consider that all weight gain has the same composition. This pitfall is often appreciated for the relative proportions of lean and fat tissue gained, but the variability of lean tissue composition has not been as widely appreciated. Total body water has been used extensively as an index of lean tissuc mass; the assumption being that the relationship between water and lean tissue is relatively 


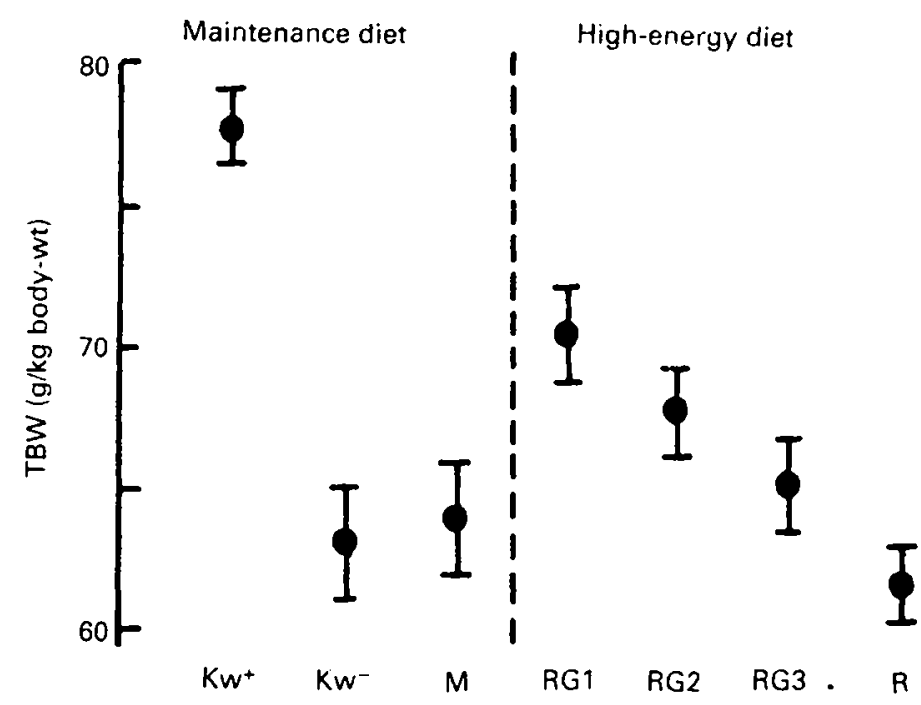

Fig. 2. Total body water (TBW) was measured in severely mainourished children on admission, while they were receiving a maintenance intake of energy and nutrients, and at times during recovery on a high-energy diet. Expressed relative to body-weight. body water was significantly greater in children with oedema ( $\left.\mathrm{Kw}^{-}\right)$ than in the same children when they had lost their oedema, ( $\left.\mathrm{Kw}^{*}\right)$, or in children who had never had oedama (M). During early catch-up growth there was a significant increase in total body water relative to body-weight for all groups of children (RG1). Total body water tended towards normal as recovery proceeded (RG2. RG3. R) (Patrick et al. 1978). Vertical bars represent standard crrors of the mean.

invariant. Patrick et al. (1978) have shown that during the early phase of rapid weight gain, children recovering from severe malnutrition demonstrate a significant increase in the relative hydration of the body, which progressively tends towards the normal as recovery proceeds (Fig. 2). Therefore, the use of total body water to derive values for lean body mass or fat mass are particularly liable to error during the early period of most rapid weight gain, although values derived from measurements of total body water may be of use when taken over the entire period of catch-up growth.

\section{BODY COMPOSITION DURING CATCH-UP GROWTH}

Assessment of changes in body composition requires an assessment of the absolute or relative contributions of water, lean and adipose to weight gain with some indication of the degree of cellular hyperplasia or hypertrophy. Unfortunately there are very few direct measures of body composition which can be applied with confidence during catch-up growth. One of the predominant changes which takes place during weight loss is a loss of muscle mass, which justifies efforts to measure muscle mass as directly as possible. A useful, but difficult approach, has been to measure muscle mass by following the dilution and kinetics of a tracer dose of $\left[{ }^{15} \mathrm{~N}\right]$ creatine (Picou et al. 1976). The method has been validated in laboratory animals for whom in vivo measurements of muscle mass correlated closely with cadaver analysis (Reeds \& Lobley, 1990). Muscle mass was measured in severely malnourished children over the course of recovery. With the attainment of an appropriate weight for their height, the muscle mass of the children was 
Table 1. Muscle mass was measured in children admitted to hospital with severe malnutrition and again after recovery (Reeds et al. 1978)

(From a muscle biopsy it was possible to calculate the changes in the muscle DNA and the non-collagen protein (NCP):DNA ratio with recovery)

\begin{tabular}{lccc}
\hline & Malnourished & Recovered \\
\hline Muscle mass $(\mathrm{kg})$ & 1.00 & 1.91 \\
& Muscle mass relative to & & 220 \\
body-wt $(\mathrm{g} / \mathrm{kg})$ & 160 & 2.05 & 2.38 \\
Muscle DNA $(\mathrm{g})$ & 153 & 265 \\
Muscle NCP $(\mathrm{g})$ & 92 & 110 \\
NCP:DNA $(\mathrm{g} / \mathrm{g})$ & & \\
\hline
\end{tabular}

approximately doubled (Table 1) (Reeds et al. 1978). As the muscle mass represented an increasing proportion of body-weight with recovery this provided some confirmation of the clinical impression of disproportionate loss of muscle in the malnourished state. In order to identify the cellular basis of these changes, the DNA and non-collagen protein content of a muscle biopsy were measured. Using this information it was possible to calculate the number of muscle nuclei and the non-collagen protein:DNA ratio, the effective 'cell size'. There was no significant difference in the total DNA of the malnourished and recovered children and the values fell about the middle of the expected range for normal children of the same height. In children in whom paired studies were carried out, a small increase in DNA was appropriate for the increase in height over the same period of time. There was an increase in the protein:DNA ratio with recovery by about $20 \%$. However, even at recovery, the protein:DNA ratio was only about $60 \%$ of the ratio that would have been expected for a child of the same height. Therefore, although recovery was complete, as defined by the attainment of an appropriate weight-for-height, the muscle mass had not shown complete recovery, even at the cellular level. Similar conclusions have been reached using more indirect methods for assessing compositional changes. Brooke \& Wheeler (1976) found that skinfold thickness was up to $99 \%$ of normal at recovery, whereas arm muscle area and total body potassium, both indices of lean tissue repletion, were 78 and $73 \%$ of normal respectively. Therefore, in relation to a normal child of the same height the children studied by Brook \& Wheeler (1976) had a body composition which consisted of an excess of fat of up to $10 \%$ and a $10-15 \%$ deficit of lean tissue. On histological examination the skeletal muscle fibre size of clinically recovered subjects, age 13.8 months, was only $60 \%$ of that for a well-nourished 6-month-old child (Hansen-Smith et al. 1979).

A somewhat different approach to assessing the nature of the tissue deposited during catch-up growth can be provided by a 'cost of growth' analysis (Jackson et al. 1977). The energy available for deposition as new tissue is related to the weight of tissue gained. For any given quantity of energy deposited, adipose tissue with an energy density of $33.4 \mathrm{~kJ} / \mathrm{g}$ will result in less weight being gained than lean tissue with an energy density of $5 \mathrm{~kJ} / \mathrm{g}$. An analysis of the energy content of the weight gain implies that in many children there is a preponderance of fat deposition.

The evidence would suggest that for many children the tissue deposited during catch-up growth tends to be relatively unbalanced, with a preponderance of adipose over 
lean tissue. 'The impressive gains in weight made by recovering malnourished infants are largely fat: reconstruction of lean tissue does not occur equally well at all rates of weight gain' (MacLean \& Graham, 1980).

Whyte et al. (1985) have reached a similar conclusion in their interpretation of the evidence relating weight gain in preterm infants to the intake of energy and protein: all studies show energy storage cost of growth (i.e. rate of accretion) much higher in low-birth-weight infants than in the fetus. Although Kashyap et al. (1988) were able to demonstrate rates of weight gain and nitrogen retention equivalent to the intrauterine rate, the intake of energy and protein had to be very finely balanced. Protein tolerance appeared to be at its limit at optimal rates of accretion. Adults recovering from severe weight loss also appear to respond in a similar way with a relative excess of adipose over lean tissue deposition, irrespective of the dietary protein intake (Elwyn et al. 1979).

Taken together the evidence shows that the tissue gained during catch-up growth is of variable composition, with a tendency towards a limitation of lean tissue deposition. The basis for the limitation is not clear, and may be primarily of either a nutritional origin, or of a constitutional or regulatory nature (see later discussion). An increase in dietary protein of itself does not appear to improve the rate of protein deposition, and it may possibly be an effect that is secondary, a consequence of some other limiting nutrient. There is evidence to suggest that under optimal conditions lean tissue is deposited in preference to adipose tissue (Rudman et al. 1975). This makes sense teleologically, providing the useful working hypothesis that the finding of an impairment of lean tissue repair implies a limited availability of one or more nutrients, or metabolic substrates. Golden \& Golden (1981) have found that when children who had recovered from severe malnutrition received oral supplements of zinc there was an increased rate of weight gain, for the same dietary intake of energy and protein, with a decreased cost of growth. From this evidence the demonstration of a shift towards lean tissue deposition with supplemental $\mathrm{Zn}$ would suggest that $\mathrm{Zn}$ may be one of the factors which limit lean tissue growth.

It can, therefore, be stated that the attainment of an appropriate weight-for-height is a necessary, but not a sufficient criterion for recovery. There is also a need to achieve a desirable body composition. If this is so then the accepted approaches to assessing catch-up growth; weight gain, nutrient balance or protein turnover cannot be used as reliable outcome indicators, as the information obtained by using these approaches cannot provide an appropriate answer to the question posed. In order to be able to explore the proposition that protein is limiting for catch-up growth it has to be accepted that this explicitly requires that the demand for protein exceeds the available supply, and that there is no limitation of any other nutrient. The imbalance between the demand and supply of protein may be of either a quantitative or qualitative nature.

\section{ACCOMMODATION TO AN IMBALANCE BETWEEN DEMAND AND SUPPLY}

We have a limited appreciation of the way in which the body accommodates, or adapts to an imbalance between the demand and supply of protein. If a protein of poor quality is ingested it can not be utilized efficiently and there is excessive urea excretion. The increased excretion has been equated, by implication, with an increase in the rate of urea production, although production itself has seldom been measured. If the amount of protein ingested is reduced significantly there is a response that seeks to conserve the 


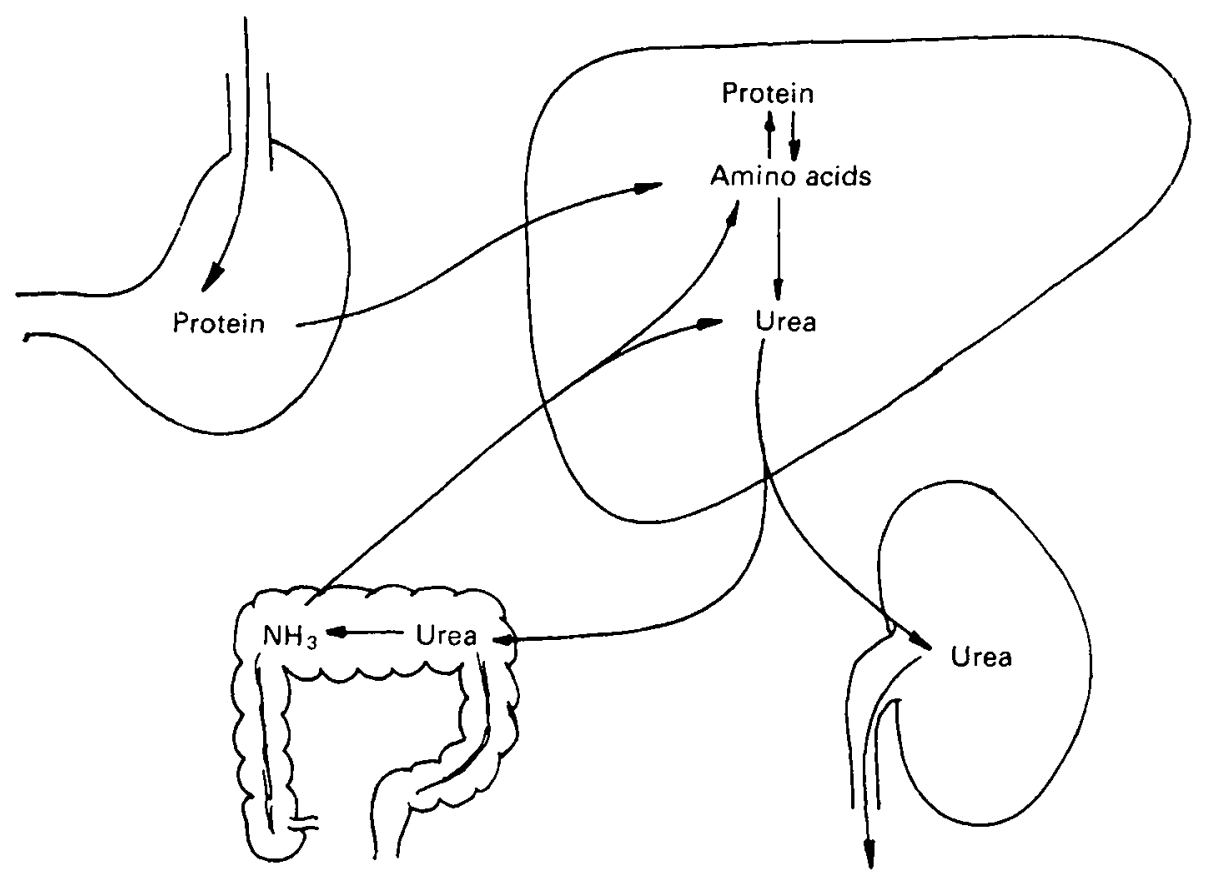

Fig. 3. Uirea is synthesized in the liver following the oxidation of amino acids from dietary and endogenous proteins. In the normal adult on an adequate protein intake $70 \%$ of the urea is excreted in the urine. with $30 \%$ being retained in the body, following hydrolysis in the gastrointestinal tract.

available nitrogen. This response is coordinated and takes place at two levels: urea production and urea excretion. On a normal, adequate protein intake about $70-80 \%$ of the urea produced in the liver is excreted in the urine, with $20-30 \%$ being salvaged through the metabolic activity of the microflora of the colon for further metabolic interaction in the host (Fig. 3). Picou \& Phillips (1972) have shown that on a marginal protein intake accommodation takes place at the level of both the liver and the colon. The rate at which urea is produced by the liver is significantly decreased and the percentage of the urea produced which is salvaged in the colon is increased from 30 to $70 \%$.

An imbalance can be produced either be decreasing the intake of protein relative to the demand, or by increasing the demand relative to the intake. Thus, in sickle cell disease the demand for protein is increased to satisfy erythrocyte production to keep pace with hacmolysis. In subjects with sickle cell disease, on a normal intake of protein, only $40 \%$ of urca production was excreted with $60 \%$ being salvaged (Jackson et al. 1988). Hence, the pattern of response to an imbalance produced by an inadequate intake appears to be essentially similar to the response to an imbalance produced by an excessive demand.

During catch-up growth there are three important factors that determine the magnitude of the demand for protein deposition and efficient utilization of dietary $\mathrm{N}$. The first is homeorrhesis: the genetic or constitutional force which canalizes growth and 


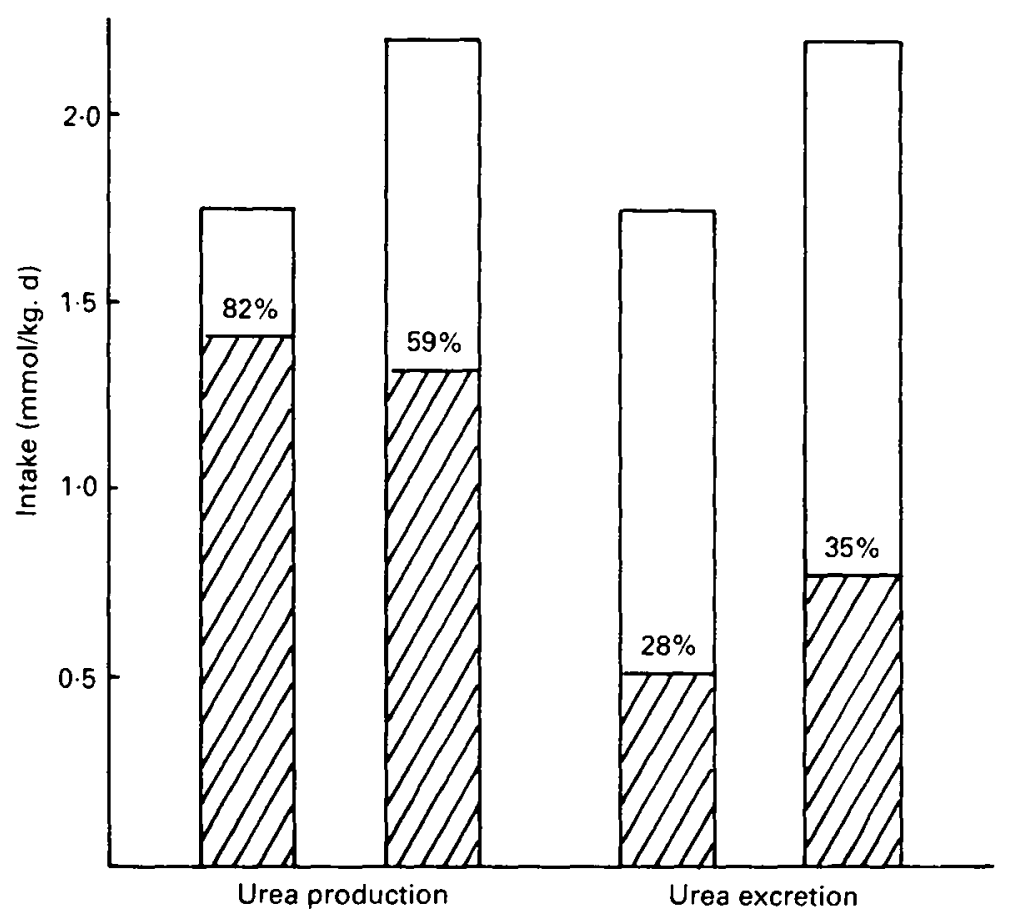

Fig. 4. Children recovering from severe malnutrition were fed one of two diets which provided $711 \mathrm{~kJ}(170$ $\mathrm{kcal}) / \mathrm{kg}$ per $\mathrm{d}$ and either $3 \cdot 7$ or $4.4 \mathrm{~g}$ protein $/ \mathrm{kg}$ per $\mathrm{d}(\square+8)$. Urea production was not different between the two groups, but on $3.7 \mathrm{~g}$ protein $/ \mathrm{kg}$ per d represented a greater percentage of the nitrogen intake. than on $4.4 \mathrm{~g}$ protein $/ \mathrm{kg}$ per $\mathrm{d}$. However, the urine excreted was less. both absolutely and relatively. on 3.7 than on $4.4 \mathrm{~g}$ protein $/ \mathrm{kg}$ per d (Doherty et al. 1989). $\square$, dietary intake of $\mathrm{N} ; \mathbb{Z}$, urea production (left) or excretion (right).

determines or seeks to achieve a particular body size and composition. Second, the energy intake determines the plane of growth and the rate at which tissue can be deposited. Third, the adequacy of other nutrients will determine the extent to which energy can be deposited as lean tissue. It is only when each of these conditions has been satisfied that it is possible to effectively assess the extent to which protein may be limiting, and hence the protein requirement for catch-up growth. There are only a few studies that have been designed in a way that enables one to make these judgements. In a series of preliminary studies on the changes that take place in urea kinetics during catch-up growth, we found that the most powerful influcnce was exerted by the energy intake which determined the rate of growth (Jackson, 1985). Hence, in any study which is designed to explore this relationship between growth and urea kinetics it is important to try to control the rate of weight gain by the careful control of energy intake.

\section{UREA-N KINETICS DURING CATCH-UP GROWTH}

We have recently completed a series of studies in which urea kinetics was measured during rapid weight gain in children who received $711 \mathrm{~kJ}(170 \mathrm{kcal}) / \mathrm{kg}$ per $\mathrm{d}$ and either 3.7 or 4.4 protein $/ \mathrm{kg}$ per $\mathrm{d}$ (Doherty et al. 1989 ) so that the percentage of energy derived 
from protein was 8.8 and 10.6 respectively. On both diets the children were in positive energy balance. However, weight gain was significantly greater on the higher protein intake, implying a lower cost of growth and more effective lean tissue deposition. Although urea excretion was greater on the higher protein intake, $\mathrm{N}$ balance was also greater, supporting the implication of increased lean tissue deposition. The results of the measures of urea kinetics were of interest as they showed a marked difference between the two dicts. Urea production was almost identical in absolute terms between the two levels of protcin, about $1.3 \mathrm{mmol} / \mathrm{kg}$ per $\mathrm{h}$. Urea production, cxpressed as a percentage of the $\mathrm{N}$ intake. was increased on the lower protein intake. reaching significance on a diet that was relatively rich in carbohydrate. These results may be interpreted as showing that the dietary $\mathrm{N}$ was utilized for protein synthesis relatively inefficiently on the low protein intake. A much more obvious difference was seen between the two levels of protein intake for the excretion of urea. Whereas on the high-protein diet $60 \%$ of the urea produced was excreted in the urine, there was very effective salvaging of urea on the low-protein diet with $65 \%$ of production being retained. Therefore, a substantial change had taken place in the internal dynamics of $\mathrm{N}$ handling between a diet that contained $8.8 \%$ of energy as protein and one that contained $10.6 \%$ (Fig. 4 ).

In the studies carried out by Picou \& Phillips (1972) the urea kinetics were measured at two levels of protein, 1.14 and $3.7 \mathrm{~g} / \mathrm{kg}$ per d, with an energy intake of $669 \mathrm{~kJ}(160$ $\mathrm{kcal}) / \mathrm{kg}$ per $\mathrm{d}$, giving the percentage of energy derived from protein as 2.9 and 9.3 . On the higher protein intake Picou \& Phillips (1972) found a pattern of urea kinetics similar to that seen on an intake of protein providing $10.6 \%$ of energy in the study of Doherty et al. (1989). Therefore, it would appear that the switch in urea kinetics takes place at an intake of about $9 \%$ protein energy. If it is possible to compare the two studies, the results would suggest that on this level of protein intake a small increment in energy intake increases the metabolic demand for protein sufficiently to change the pattern of urea kinetics. It may be that the amino acid pattern of the proteins that are to be synthesized with the additional energy is markedly different from that of the dietary intake, leading to an inefficient use of dietary protein and an increase in urea production. Notwithstanding the increase in urea production, the salvage system is sufficiently effective to offset this imbalance by an enhancement of the re-utilization of the $\mathrm{N}$ coming from the hydrolysis of urea (Fig. 4).

\section{ENHANCED UTILIZATION OF UREA-N}

Although there are few detailed studies of the rate at which urea is produced and salvaged under conditions of nutritional stress, the information available indicates that the pattern of response might conform to a general pattern. The most rapid rates of postnatal growth are obtained during early infancy. Urea is effectively retained during carly infancy, and may make an important contribution to the $\mathrm{N}$ economy of the body (Jackson, 1989). It is clearly recognized that a negative $\mathrm{N}$ balance accompanies metabolic stress, leading to the need for retention of $N$ during recovery. Moran et al. (1989) have shown that in postoperative patients being treated with total parenteral nutrition for intestinal failure there is substantial retention of urea- $N$, well into the recovery period (Fig. 5).

The concept of the need to salvage urea- $\mathrm{N}$ to satisfy the metabolic demand for $\mathrm{N}$ is in keeping with the idea that 'non-cssential $N$ ' might be limiting for growth. For some time 


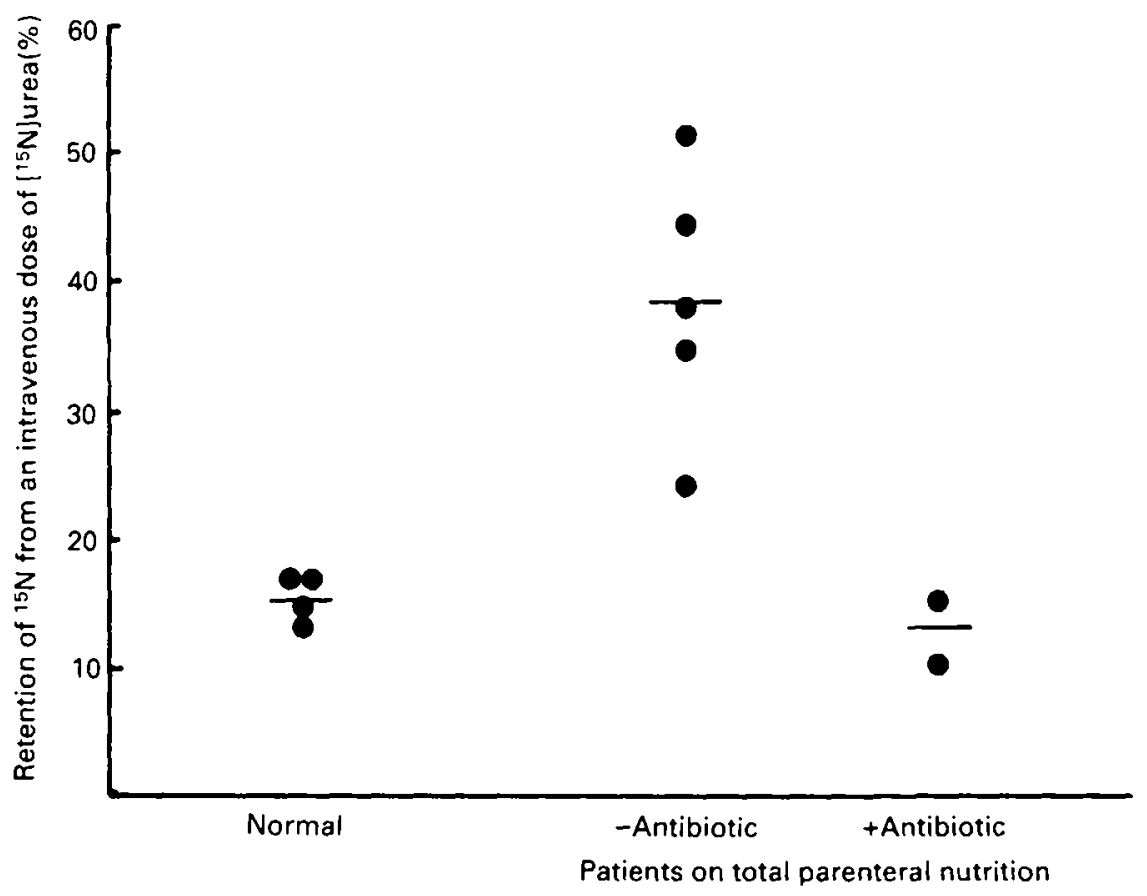

Fig. 5. The retention of labelled nitrogen was measured following the intravenous infusion of a single dose of $\left[{ }^{5} \mathrm{~N},{ }^{15} \mathrm{~N}\right]$ urea. Patients on total parenteral nutrition rctained significantly more label than normal controls, but the difference was abolished in those patients who were receiving antibiotics (Moran et al. 1990). Horizontal bars represent means.

we have been exploring the consideration that glycine specifically is functionally essential during periods of rapid growth. Reeds (1990) has discussed in some detail the extent to which glycine may act as the first limiting nutrient for protein deposition generally. We have used 5-oxoprolinuria as an index of glycine insufficiency, and have demonstrated that 5-oxoprolinuria is present during pregnancy (Persaud et al. 1989), in newborn infants (Persaud et al. 1990) and during rapid catch-up growth from malnutrition (Persaud et al. 1987). Most recently Moran et al. (1989) observed that during recovery from surgical stress there is a highly significant increase in the urinary excretion of 5-oxoproline that only slowly returns towards normal. Our observations would support the proposal by Reeds (1990) that non-essential $\mathrm{N}$ might be of great importance in situations of catch-up growth. Salvaging and recycling of urea- $\mathrm{N}$ is of special significance in this respect. The quantification of endogenous production of specific amino acids, such as glycine, and the extent to which this satisfies the functional demand should be the focus of future research in this area.

\section{REFERENCES}

Ashworth. A. (1979). Progress in the treatment of protein-energy malnutrition. Proceedings of the Nutrition Society 38, 89-97.

Brooke, O. G. \& Whecler, E. F. (1976). High energy feeding in protein-energy malnutrition. Archives of Disease in Childhood 51, 968-971. 
Doherty, T., deBenoist, M.-H., Hibbert, J., Persaud, C. \& Jackson, A. A. (1989). The effect of the level of dietary protein and the quality of dietary energy on urea kinetics in young children recovering from severe malnutrition. Proceedings of the Nutrition Society 48, 55A.

Elwyn, D. H., Gump. F. E., Munro, H. N., Iles, M. \& Kinney, J. M. (1979). Changes in nitrogen balance of depleted patients with increasing infusions of glucose. American Journal of Clinical Nutrition 32. $1597-1.611$.

Golden, M. H. N. \& Golden, B. E. (1981). Effect of zinc supplementation on the dietary intake, rate of weight gain, and energy cost of tissue deposition in children recovering from severe malnutrition. American Journal of Clinical Nutrition 34, 900-908.

Golden, M., Waterlow, J. C. \& Picou, D. (1977). The relationship between dietary intake, weight change, nitrogen balance, and protein turnover in man. American Journal of Clinical Nutrition 30, 1345-1348.

Hansen-Smith, F. M., Picou, D. \& Golden, M. H. N. (1979). Growth of muscle fibres during recovery from severe malnutrition in Jamaican infants. British Journal of Nutrition 41, 275-282.

Jackson, A. A. (1985). Nutritional adaptation in disease and recovery. In Nutritional Adaptation in Man. pp. 111-126 [K. Blaxter and J. C. Waterlow, editors]. London: John Libbey \& Co.

Jackson, A. A. (1989). Optimizing amino acid and protein supply and utilization in the newborn. Proceedings of the Nutrition Society 48, 293-301.

Jackson, A. A., Landman, J. P., Stevens, M. C. G. \& Serjeant, G. R (1988). Urea kinetics in adults with homozygous sickle cell disease. European Journal of Clinical Nutrition 42, 491-496.

Jackson, A. A., Picou, D. \& Reeds, P. J. (1977). The energy cost of repleting tissue deficits during recovery from protein enetgy malnutrition. American Journal of Clinical Nutrition 30, 1514-1517.

Kashyap, S., Schulze, K., Forsyth, M., Zucker, C., Dell, R. B., Ramakrishnan, R. \& Heird, W. C. (1988). Growth, nutrient retention, and metabolic response in low birth weight infants fed varying intakes of protein and energy. Journal of Pediatrics 113, 713-721.

MacLean, W. C. \& Graham, G. G. (1980). The effect of energy intake on nitrogen content of weight gained by recovering malnourished children. American Journal of Clinical Nutrition 33, 903-909.

Moran, B., Karran, S. J. \& Jackson, A. A. (1990). Increased retention of urea nitrogen in patients on total parenteral nutrition. Proceedings of the Nutrition Society 49, 104A.

Moran, B., Persaud, C. \& Jackson, A. A. (1989). Urinary excretion of 5-oxoproline in severe inflammatory illness. Proceedings of the Nutrition Society $48,75 \mathrm{~A}$.

Patrick, J., Reeds, P. J., Jackson, A. A., Seakins, A. \& Picou, D. I. M. (1978). Total body water in malnutrition: the possible role of energy intake. British Journal of Nutrition 39, 417-424.

Persaud, C., Evans, N., Rutter, N., Hall, M., Smith, S. \& Jackson, A. A. (1990). The urinary excretion of 5-oxoproline in healthy term infants. Proceedings of the Nutrition Society 49, 6A.

Persaud, C., Forrester, T. \& Jackson, A. A. (1987). Glycine: limiting amino acid for rapid growth. Proceedings of the Nutrition Society 46, 136A.

Persaud, C., McDermott, J., deBenoist, B. \& Jackson, A. A. (1989). The excretion of 5-oxoproline as an index of glycine status, during normal pregnancy. British Journal of Obstetrics and Gynaecology 96, 440-444.

Picou. D. \& Phillips, M. (1972). Urea metabolism in malnourished and recovered children receiving a high or a low protein diet. American Journal of Clinical Nutrition 25, 1261-1266.

Picou, D., Reeds, P. J. Jackson, A. A. \& Poulter, N. (1976). The measurement of muscle mass in children using $\left[{ }^{15} \mathrm{~N}\right] \mathrm{creatine}$. Pediatric Research 10, 184-188.

Reeds, P. J. (1990). Amino acid needs and protein scoring patterns. Proceedings of the Nurrition Society 49, $489-497$.

Reeds, P. J., Jackson, A. A., Picou, D. \& Poulter, N. (1978). Muscle mass and composition in malnourished infants and children and changes seen after recovery. Pediatric Research 12, 613-618.

Reeds, P. J. \& Lobley. G. E. (1990). A comparison of skeletal muscle mass in rabbits as measured by dissection and by creatine dilution. Proceedings of the Nutrition Society 49, 81A.

Rudman, D., Millikan, W. J., Richardson, T. J., Bixler, T. J. II, Stackhouse, J. \& McGarrity, W. C. (1975). Elemental balances during intravenous hyperalimentation of underweight adult subjects. Journal of Clinical Investigations 55, 94-104.

Waterlow, J. C. (1961). The rate of recovery of malnourished infants in relation to the protein and calorie levels of the diet. Journal of Tropical Pediatrics 7, 16-22.

Whyte, R. K., Bayley, H. S. \& Sinclair, J. C. (1985). Energy intake and nature of growth in low birth weight infants. Canadian Journal of Physiology and Pharmacology 63, 565-570. 